Стахів О. А., к.е.н., доцент (Національний університет водного господарства та природокористування, м. Рівне)

\title{
ДОСЛІДЖЕННЯ СТАНУ УПРАВЛІННЯ ТОВАРНИМИ ЗАПАСАМИ ПІДПРИЕМСТВА РОЗДРІБНОЇ ТОРГІВЛІ
}

Проблема управління товарними запасами є однією з ключових в системі управління оборотними активами підприємств роздрібної торгівлі. Вона спрямована на вирішення ряду задач, серед основних з яких є задоволення попиту покупців та збільшення прибутковості підприємства. В статті досліджуються основні питання оцінки стану управління товарними запасами на підприємствах роздрібної торгівлі.

Ключові слова: торговельне підприємство, товарні запаси, товарооборот, чистий прибуток, управління товарними запасами.

Основним призначенням товарних запасів, що знаходяться на торгових підприємствах - створення стабільної сталої пропозиції товарів в залежності від попиту покупців. При цьому пропозиція товарів має бути відображена у вигляді сформованого набору товарів для певного виду торгового підприємства. Проблема управління товарними запасами $є$ однією з ключових в системі управління оборотними активами підприємств роздрібної торгівлі та спрямована на вирішення ряду задач, серед основних з яких $є$ задоволення попиту покупців, забезпечення безперервності процесу формування й реалізації запасів, оптимізації витрат на їх обслуговування та як наслідок збільшенні прибутковості підприємства. Оскільки, товарні запаси є складовими елементами фінансового циклу, то виникає проблема в раціональному зменшенні тривалості їх обороту на підприємствах торгівлі.

Проблеми оцінки стану товарних запасів та ефективності управління ними на підприємствах торгівлі досліджувались у роботах відомих вітчизняних та зарубіжних вчених, зокрема О. Бакунова, I. Бланка, В. Білика, Р. Брейлі, Б. Джордана, П. Етрила, В. Ковальова, Д. Кузнецова, С. Майерса, К. Олініченко, Дж. К. Ван Хорна, А. Шеремета та інших. Проте, враховуючи важливість даної проблеми виникає потреба в більш детальному її дослідженні. 
Метою даної статті є виявлення тенденцій зміни стану управління та динаміки товарних запасів на підприємстві роздрібної торгівлі.

Торгівля на сучасному етапі соціально-економічного розвитку нашої країни виступає як своєрідний каталізатор, активізуючи товарний обіг, сприяючи тим самим досягненню основної мети суспільного виробництва - найбільш повному задоволенню існуючих та можливих потреб суспільства.

За допомогою роздрібної торгівлі формується специфічний продукт - послуга роздрібної торгівлі, яка призначена, в сукупності з товарами, для задоволення потреб окремого споживача. В якості кінцевого споживача виступають, як правило, фізичні особи, які мають намір придбати товар, скористатися послугами або користуються придбаним товаром, тобто споживають послугу або використовували останнє в вищезазначених цілях.

Будь-яке підприємство торгівлі закупає товари для подальшого продажу з метою отримання прибутку. Щоб задовольнити потреби покупців і організувати безперебійну торгівлю, необхідно мати достатню кількість товарів у запасі, а значить, слід організувати їх раціональне придбання та зберігання [1; 2].

Зв'язок торгівлі з грошовим обігом характеризує специфіку виконання підприємствами торгівлі функції обміну і впливає на величину та ефективність використання ними товарних запасів. Висока швидкість обігу товарних запасів пояснює практично щоденну потребу в поповненні платіжних коштів у торговельного підприємства, для забезпечення якої воно залучає ресурси із зовнішніх джерел, що пов'язано з процесами кредитування [3, С. 45].

Запас як явище в роботі логістичних систем і ланцюгів поставок представляє собою товарно-матеріальні цінності, що очікують споживання. Запас (slock, inventory) - те, що приготовлене, призначене для подальшого споживання.

Будь-який товар належить до категорії товарного запасу до моменту продажу. 3 економічної точки зору ця форма існування товару $є$ статичною. Ця обставина, зокрема, означає, що товарний запас $є$ величиною моментною. Товарні запаси можуть змінювати свій розмір, так як поступово втягуються в товарообіг, продаються, перестають бути запасами. Так як вони замінюються іншими партіями товарів, тобто відновлюються регулярно, запаси представляють собою постійно існуючу величину, розмір якої змінюється відповідно до конкрет- 
них господарськими умовами.

Асортимент товарних запасів на підприємствах роздрібної торгівлі налічує декілька тисяч найменувань, а тому досить важко спрогнозувати їх реалізацію. Відповідно виникають ситуації при яких товарні запаси залежуються, а тому підприємство змушене знижувати його вартість з метою відшкодування витрат, що пов'язаних з їх придбанням.

Раціональне формування товарних запасів та їх координація одна з головних умов забезпечення поглибленого відтворення товарів, в тому числі і безперервної реалізації товарів, для цілковитого задоволення попиту населення при мінімальних витратах виробництва і обігу.

На підприємствах торгівлі питома вага запасів вище, ніж в інших видах економічної діяльності в цілому, тому управлінню запасами в торгівлі повинна приділятися особлива увага.

Метою управління є ефективний вплив на об'єкт управління запаси, що дозволяє підприємству не створювати дефіциту товарів і створювати такі запаси, які позитивно впливають на фінансовий стан підприємства.

Управління товарними запасами в торгівлі дозволяє уникнути перебоїв у товарозабезпеченні та не допустити затоварювання складу або магазину.

Управління запасами - складна сфера діяльності, залежна від множини різними факторами і впливає на інші функції компанії. Процес управління товарними запасами забезпечує сумісність операцій із запасами всередині компанії та поза нею, на всіх етапах ланцюга створення додаткової вартості, в який включена компанія. В політиці управління запасами на окремому підприємстві повинні бути визначені процедури та показники такої діяльності.

Процес експрес-оцінювання ефективності управління товарними запасами підприємства роздрібної торгівлі пропонується проводити за методикою, запропонованою К. Олініченко [3, С. 76-78].

Для отримання адекватних і повних результатів доцільно проводити відповідні розрахунки з урахуванням інформації не менше, як за два попередні роки. Розрахунки здійснено на прикладі ТзОВ фірма «Ольвія» в таблиці. 
Динаміка показників товарних запасів ТзОВ фірма «Ольвія»

\begin{tabular}{|c|c|c|c|c|c|c|}
\hline \multirow{2}{*}{ Показники } & \multirow{2}{*}{$\begin{array}{c}\text { Умовні по- } \\
\text { значення }\end{array}$} & \multicolumn{3}{|c|}{ Роки } & \multicolumn{2}{|c|}{ Темп зміни } \\
\hline & & 2015 & 2016 & 2017 & $2016 / 2015$ & $2017 / 2016$ \\
\hline 1 & 2 & 3 & 4 & 5 & 6 & 7 \\
\hline $\begin{array}{lr}\text { Чистий } \\
\text { буток, тис. грн }\end{array}$ & $\Phi P$ & 393 & 353 & -787 & 0,90 & $-2,2$ \\
\hline $\begin{array}{l}\text { Товарні запа- } \\
\text { си, тис. грн }\end{array}$ & T3 & 5805 & 7065 & 7436 & 1,22 & 1,05 \\
\hline $\begin{array}{l}\text { Товарооборот, } \\
\text { тис. грн }\end{array}$ & TO & 393 & 353 & -787 & 0,976 & 1,141 \\
\hline $\begin{array}{l}\text { Питома вага } \\
\text { товарних за- } \\
\text { пасів в сукуп- } \\
\text { них активах, } \\
\text { у частках }\end{array}$ & $d_{T 3}$ & 0,669 & 0,710 & 0,713 & 1,062 & 1,004 \\
\hline $\begin{array}{l}\text { Питома вага } \\
\text { товарних за- } \\
\text { пасів в оборо- } \\
\text { тних активах, } \\
\text { у частках }\end{array}$ & $d_{\text {T3оa }}$ & 0,891 & 0,909 & 0,905 & 1,020 & 0,996 \\
\hline
\end{tabular}

Підприємство працює у галузі торгівлі будівельними матеріалами та санітарно-технічним обладнанням, де на сьогодні існує досить велика конкуренція.

1. Визначення наявності чистого прибутку (або збитку) підприємства та порівняння темпів зміни чистого прибутку та товарних запасів. Визначення обсягу фінансового результату від операційної діяльності ( ФР) та величини товарних запасів (ТЗ) підприємства роздрібної торгівлі проводиться $з$ метою виявлення основних тенденцій їх динаміки за період. Далі відбувається порівняння динаміки обсягу фінансового результату від операційної діяльності $\left(T_{\phi P}\right)$ та величини товарних запасів $\left(T_{T 3}\right)$ підприємства.

Наявність прибутку в підприємствах $є$ першою ознакою ефективного управління товарними запасами. Позитивна динаміка фінансового результату від операційної діяльності, тобто $T_{\phi P} \geq 1$ характерна для періоду 2015-2016 років.

Умова $T_{\Phi P} \geq T_{T 3}$ не виконується на підприємстві, що свідчить про низьку ефективність управління товарними запасами 
Управління товарними запасами вважається ефективним за умови отримання позитивного значення фінансового результату від операційної діяльності та перевищення темпів його зростання над темпами росту товарних запасів. В інших випадках, особливо за наявності негативного значення фінансового результату, управління товарними запасами визнається неефективним, що відбувається на ТзОВ фірма «Ольвія». Тобто підприємство має певні проблеми у даній сфері

2. Визначення частки товарних запасів у сукупних активах $\left(d_{T 3}\right)$ підприємства роздрібної торгівлі та ії динаміки за період дослідження із товарними запасами підприємства роздрібної торгівлі наступним порівнянням із динамікою фінансового результату від операційної діяльності. Зростання частки запасів у сукупних активах за наявності збитків (низької величини позитивного фінансового результату від операційної діяльності) $є$ однією з причин неефективності або низької ефективності діяльності підприємства роздрібної торгівлі

3. Визначення частки товарних запасів в оборотних активах $\left(d_{\text {тзоа }}\right)$ підприємства роздрібної торгівлі та ії динаміки за період дослідження із наступним порівнянням 3 динамікою фінансового результату від операційної діяльності.

У кругообігу оборотних активів товарні запаси відіграють вирішальну роль, оскільки з ними пов'язана значна частина всіх оборотних активів та можливість генерування основного фінансового результату господарської діяльності - прибутку. Тому третьою ознакою відсутності в підприємства ефективного управління товарними запасами є зростання їх частки в оборотних активах при загальній збитковості або низькій величині позитивного фінансового результату від операційної діяльності.

Прибутковість ТзОВ фірма «Ольвія» протягом досліджуваного періоду зменшується, супроводжуючись зростанням питомої ваги товарних запасів в оборотних активах, що також свідчить про неефективність їх управління. Іншими словами, присутня ситуація, коли зростаючі товарні запаси приносять менший прибуток. Можна зробити висновок, що зростання частки товарних запасів $€$ однією з причин неефективності або низької ефективності діяльності підприємства роздробної торгівлі.

Зростання частки запасів в оборотних активах за наявності збитків (низької величини позитивного фінансового результату від операційної діяльності) є симптомом неефективності діяльності підприємства та, відповідно, свідчить про неефективне управління то- 
варними запасами.

4. Стан товарних запасів значно впливає на показники господарської та фінансової діяльності торговельного підприємства: обсяг товарообороту (TO) і витрати на продаж товарів, а отже, і прибуток від продажів, стан матеріально-технічної бази, величину оборотних коштів, рівень забезпеченості власними оборотними коштами. Зайві товарні запаси призводять до збільшення витрат з їх утримання, що негативно впливає на прибуток, та до додаткового залучення джерел фінансування, уповільнення оборотності вкладених коштів, що сприяє погіршенню фінансової стійкості і платоспроможності. 3 іншого боку, недостатня їх величина викликає перебої в торговельному процесі, втрати товарообороту у зв'язку з можливим незадоволеним купівельним попитом, що скорочує валовий прибуток (реалізовану торгову націнку), а отже, і кінцевий фінансовий результат. Виходячи з вище наведеного, ефективність управління товарними запасами залежить від якісного рівня аналітичної роботи на підприємстві роздрібної торгівлі, глибини економічної оцінки, що проводиться, та обґрунтованості ї̈ висновків.

Тенденція зміни товарних запасів виявляється на базі побудови фактичних динамічних рядів за середніми запасами за період. Відзначимо, що вивченню товарних запасів в динаміці необхідно приділити особливе значення в поглибленій оцінці саме 3 метою виявлення основних закономірностей їх розвитку, оцінки співвідношення, що склалися між зміною запасів та товарооборотом, визначення забезпеченості товарообороту товарною масою.

Як видно з таблиці, відбувалося зростання товарообороту в 2017 році порівняно з попереднім. При цьому темпи зростання у 2016 р. в порівнянні 32015 р. перевищували темпи зростання товарних запасів.

Виконання цієї умови свідчить про прискорення товарооборотності, що, у свою чергу, призводить до відносної економії витрат і зростання прибутку, відносного вивільнення оборотних коштів при заданих обсягах діяльності тощо. Але в підприємства в 2017 році значно погіршилися фінансові результати діяльності.

у підприємства обсяг товарообороту у 2016 р. в порівнянні 3 2015 р. зменшився.

Для наочності дані таблиці доповнимо побудовою діаграми (рисунок). 


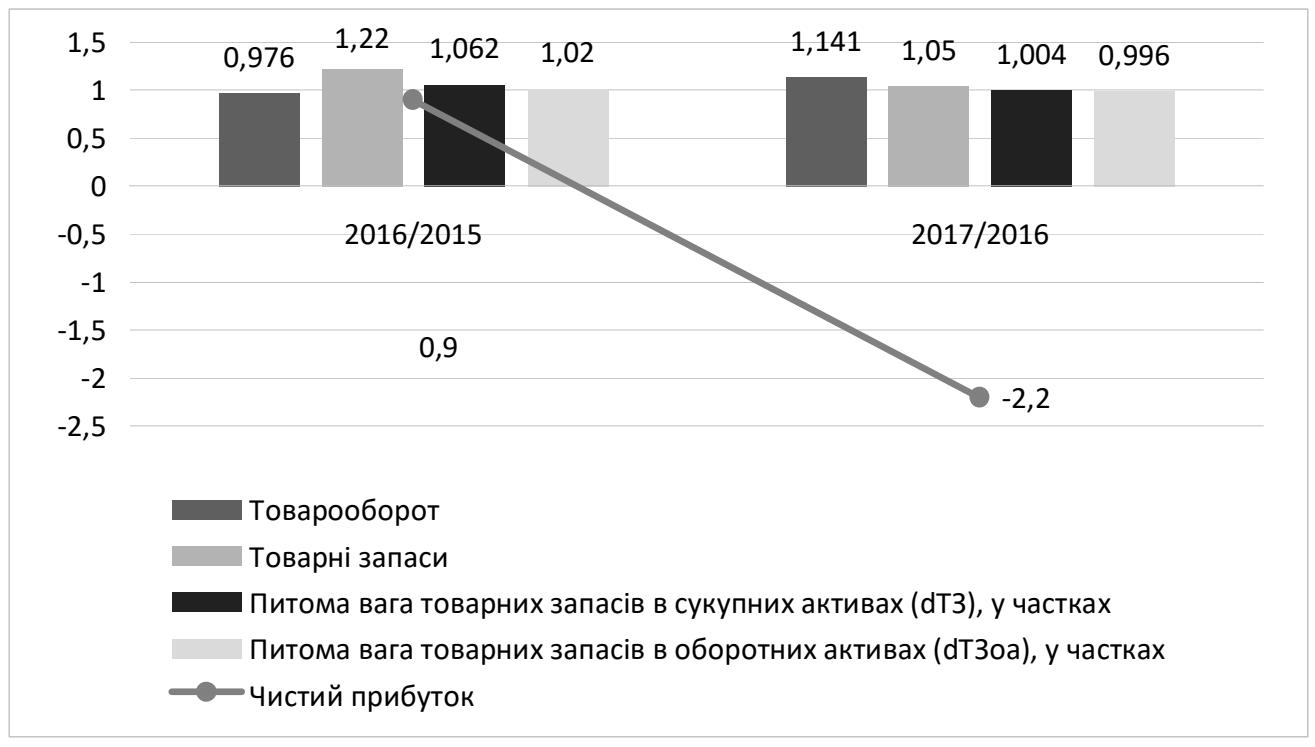

Рисунок. Тенденції зміни показників оцінки товарних запасів ТзОВ фірма «Ольвія», темпи росту

Після оцінки стану та тенденції зміни товарних запасів вирішується наступне завдання - оцінка ефективності їх використання, яка традиційно здійснюється на базі показників оборотності.

Управління товарними запасами в торгівлі $є$ одним з ключових елементів формування торгової політики підприємства. Відхилення від оптимальних показників в бік зменшення залишків товарів веде до недоотримання виторгу, а надлишки товарних запасів - до додаткових витрат на зберігання, втрат на простроченні i, як наслідок, зниження оборотності. У зв'язку з цим слід вести оперативний облік і контроль над станом товарних запасів, оскільки своєчасно виявлені відхилення дозволять прийняти грамотні управлінські рішення та не допустити втрат.

Грамотно реалізуючи весь комплекс з організації управління товарними запасами на підприємстві, можна заощадити значну частину коштів від вартості запасів, витрат на їх утримання та на підтримку складських приміщень.

1. Бакунов 0., Крещенко О. Формування стратегії управління товарними запасами торговельного підприємства на засадах категорійного менеджменту. Торгівля і ринок України : зб. наук. праць. 2012. Вип. 33. С. 119-127. 2. Бі- 
лик В. М., Закусілов О. А. До питання про вживання термінів «товарні ресурси» і «товарні запаси». Науковий вісник Національного лісотехнічного університету України : зб. наук.-техн. пр. Львів, 2011. Вип. 21.2. С. 171-175. 3. Олініченко К. С. Управління товарними запасами підприємств роздрібної торгівлі : монографія. Х. : Видавництво Іванченка І. С., 2017. 211 с.

\section{REFERENCES :}

1. Bakunov 0., Kreshchenko 0. Formuvannia stratehii upravlinnia tovarnymy zapasamy torhovelnoho pidpryiemstva na zasadakh katehoriinoho menedzhmentu. Torhivlia i rynok Ukrainy: zb. nauk. prats. 2012. Vyp. 33. S. 119-127. 2. Bilyk V. M., Zakusilov 0. A. Do pytannia pro vzhyvannia terminiv «tovarni resursy» i «tovarni zapasy». Naukovyi visnyk Natsionalnoho lisotekhnichnoho universytetu Ukrainy : zb. nauk.-tekhn. pr. Lviv, 2011. Vyp. 21.2. S. 171-175. 3. Olinichenko K. S. Upravlinnia tovarnymy zapasamy pidpryiemstv rozdribnoi torhivli : monohrafiia. Kh. : Vydavnytstvo Ivanchenka I. S., 2017. $211 \mathrm{~s}$.

Рецензент : к.е.н., професор Кушнір Н. Б. (НУВГП)

Stakhiv 0. A., Candidate of Economics (Ph.D.), Associate Professor, (National University of Water and Environmental Engineering, Rivne)

\section{RESEARCH STATE OF COMMERCIAL RESERVES OF RETAIL TRADE ENTERPRISE}

A problem of control of commodity inventories is one of key in control system by the circulating assets of enterprises of retail business. It is aimed at solving a number of tasks, among which the main ones are to meet the demand of customers and increase the profitability of the enterprise. The article deals with the main questions of assessing the state of inventory management at retail enterprises Keywords: trade enterprise, commodity stocks, turnover, net profit, management of commodity stocks. 
Стахив О. А., к.э.н., доцент (Национальный университет водного хозяйства и природопользования, г. Ровно)

\section{ИССЛЕДОВАНИЕ СОСТОЯНИЯ УПРАВЛЕНИЯ ТОВАРНЫМИ ЗАПАСАМИ ПРЕДПРИЯТИЯ РОЗНИЧНОЙ ТОРГОВЛИ}

Проблема управления товарными запасами является одной из ключевых в системе управления оборотными активами предприятий розничной торговли. Она направлена на решение ряда задач, среди основных из которых является удовлетворение спроса покупателей и увеличения прибыльности предприятия. В статье исследуются основные вопросы оценки состояния управления товарными запасами на предприятиях розничной торговки.

Ключевые слова: торговое предприятие, товарные запасы, товарооборот, чистая прибыль, управление товарными запасами. 